\title{
Characterization of angiotensin II receptors (binding and mRNA) in the rat thyroid gland
}

\section{Montiel and E Jiménez}

Departamento de Bioquímica y Biología Molecular, Facultad de Medicina, Universidad de Málaga, 29080 Málaga, Spain

(Requests for offprints should be addressed to E Jiménez)

\begin{abstract}
In this study we showed, for the first time, the existence of a moderate density of specific angiotensin II (Ang II) binding sites $\left(K_{\mathrm{d}}=3 \cdot 9 \pm 1 \cdot 7 \mathrm{nM}\right.$ and $\mathrm{B}_{\max }=467 \cdot 2 \pm 130 \cdot 0 \mathrm{fmol} / \mathrm{mg}$ protein) in plasma membrane preparations from rat thyroid gland. Reverse transcriptase/polymerase chain reactions, using primers based on the cloned $\mathrm{AT}_{1}$ and $\mathrm{AT}_{2}$ receptor subtypes, and pharmacological characterization, using the Ang II receptor subtype antagonists Losartan and PD 123319, revealed that these Ang II binding sites match with the $\mathrm{AT}_{1}$ receptor subtypes. To obtain more information on the molecular structure of this Ang II receptor, immunoblotting analyses were carried out using
\end{abstract}

a polyclonal rabbit anti-AT $\mathrm{T}_{1}$ antiserum. Western analysis of fresh plasma membrane preparations from thyroid tissue showed three prominent bands of approximately 60,45 and $40 \mathrm{kDa}$ which appear to be related to different degrees of glycosylation of the receptor molecule. The functional significance of the Ang II receptors in thyroid gland is currently not known. Nevertheless, since Ang II receptors play a pivotal role in the co-ordinated actions of the renin-angiotensin system (RAS), our findings support a reciprocal regulation of thyroid function by the RAS.

Fournal of Molecular Endocrinology (1998) 20, 299-304

\section{INTRODUCTION}

Angiotensin II (Ang II) is a well-characterized peptide of the renin-angiotensin system (RAS) involved in cardiovascular homeostasis. In addition, Ang II stimulates cell growth and proliferation (Schelling et al. 1991, Steckelings et al. 1996), and expression of growth factors and growth-related proto-oncogenes (Naftilan et al. 1989). All these effects of Ang II are mediated by its binding to specific receptors. Two different Ang II receptor subtypes, $\mathrm{AT}_{1}$ and $\mathrm{AT}_{2}$, have been characterized by pharmacological, biochemical and molecular cloning techniques (Whitebread et al. 1989, Sasaki et al. 1991, Kambayashi et al. 1993).

Ang II receptor subtypes are not uniformly distributed in all somatic tissues. While some tissues express a nearly homogeneous population of the $\mathrm{AT}_{1}$ receptor subtype (liver, lung, kidney and placenta) or $\mathrm{AT}_{2}$ receptor subtype (pancreas and ovarian granulosa), other tissues express both receptor subtypes (adrenal, brain, uterus and heart). The physiological significance of this heterogeneous distribution of the Ang II receptor subtypes has not yet been determined but should be important since both receptor subtypes appear to be involved in different physiological events. In general, the $\mathrm{AT}_{1}$ receptor subtype predominates in tissues which are involved in fluid-electrolyte balance and blood pressure regulation (De Gasparo et al. 1995), while the $\mathrm{AT}_{2}$ receptor subtype, which is predominantly expressed in the early stages of life (Zemel et al. 1990, Hermann et al. 1991) and re-expressed in the adult in various pathological situations (Janiak et al. 1992, Viswanathan \& Saavedra 1992), has been suggested to play a role in tissue growth and/or differentiation (Viswanathan \& Saavedra 1994, Harris \& Inagami 1995, Breault et al. 1996).

The existence of a relationship between thyroid function and the renin-angiotensin-aldosterone system (RAAS) has been previously recognized. It is well known that thyroid hormone excess or deficiency affects several components of the RAAS, such as plasma renin activity, plasma renin concentration and plasma renin substrate and aldosterone levels (Jiménez et al. 1984, Montiel et al. 1984, Ruiz et al. 1987, Catanzaro 1995). Moreover, Ang II receptor densities in rat heart, 
liver, kidney and adrenal gland have been found to be altered in thyroid dysfunction (Marchant et al. 1993, Matillas et al. 1993). Nevertheless, if the biologically active peptides of the RAS, such as Ang II, exert a regulating control of thyroid function, it has not yet been established. The purpose of this study was to investigate the existence of Ang II binding sites in the rat thyroid gland and to assess some of their binding and molecular properties. For the first time the gene expression and the pharmacological characterization of Ang II binding sites from thyroid gland of rats have been studied.

\section{MATERIALS AND METHODS}

\section{Animals and preparation of plasma membranes}

Male adult Wistar rats were housed under a schedule of $14 \mathrm{~h}$ light:10 $\mathrm{h}$ darkness and maintained on a normal laboratory diet with tap water available ad libitum. Plasma membranes were prepared from rat thyroid glands as previously described by Glossmann et al. (1974). In brief, tissue was homogenized in ice-cold $20 \mathrm{mM}$ sodium bicarbonate, containing $1 \mu \mathrm{g} / \mathrm{ml}$ leupeptin and aprotinin, and $0.1 \mu \mathrm{g} / \mathrm{ml}$ bacitracin and phenylmethylsulphonyl fluoride (Sigma Chemical Co., St Louis, MO, USA). The homogenate was centrifuged at $900 \boldsymbol{g}$ for $15 \mathrm{~min}$ at $4{ }^{\circ} \mathrm{C}$. The pellet was resuspended in the same buffer and recentrifuged. The pooled supernatants were then centrifuged at $30000 \mathrm{~g}$ for $30 \mathrm{~min}$ at $4{ }^{\circ} \mathrm{C}$ and the pellet was resuspended in incubating buffer $(50 \mathrm{mM}$ Tris- $\mathrm{HCl}, \mathrm{pH} \mathrm{7} \cdot 4$, containing $120 \mathrm{mM} \mathrm{NaCl}, 6 \mathrm{mM}$ $\mathrm{MgCl}_{2}, 0 \cdot 1 \% \mathrm{BSA}$ and proteinase inhibitors).

\section{Binding assays}

To investigate Ang II receptor binding characteristics, ${ }^{125} \mathrm{I}-\mathrm{Ang}$ II $(0 \cdot 1 \mathrm{nM}$, specific activity $2000 \mathrm{Ci} / \mathrm{mmol}$; Amersham International plc, Amersham, Bucks, UK) was incubated with thyroid gland membrane fractions $(50 \mu \mathrm{g}$ protein) in $150 \mu \mathrm{l}$ incubating buffer at $25{ }^{\circ} \mathrm{C}$ for $45 \mathrm{~min}$ in the presence or absence of varying concentrations of unlabelled Ang II (Sigma Chemical Co.) or the Ang II receptor subtype antagonists Losartan (Ciba-Geigy Ltd, Basel, Switzerland) and PD 123319 (Parke Davis, Ann Arbor, MI, USA). Bound and free radioactivity was separated by adding $4.0 \mathrm{ml}$ of ice-cold saline to the assay tube, followed by vacuum filtration through Millipore filters (Millipore Iberica, Madrid, Spain) presoaked with assay buffer. The assay tubes and filters were then rinsed with three additional washes of $4.0 \mathrm{ml}$ cold saline buffer and the filters counted in a $\gamma$-counter (Diagnostic Products Corporation, Los Angeles, CA, USA). Equilibrium dissociation constant $\left(K_{\mathrm{d}}\right)$ and concentration of receptor sites $\left(\mathrm{B}_{\max }\right)$ were determined from the competition curves using the iterative curve-fitting programme Ligand (Dr P J Munson, NICHD, NIH, Bethesda, MD, USA; Munson \& Rodbard 1980). Non-specific binding was defined as radioactivity bound in the presence of $10 \mu \mathrm{M}$ Ang II in the incubation medium.

\section{Tissue collection and RNA extraction}

Rats were killed by cervical dislocation and thyroid glands were quickly removed and frozen in liquid nitrogen. Total RNA was isolated by means of guanidine thiocyanate as previously described by Chomczynki \& Sacchi (1987).

\section{First strand cDNA synthesis and PCR assay}

Total RNA $(1 \mu \mathrm{g})$ was subjected to first strand cDNA synthesis in a $20 \mu \mathrm{l}$ reaction volume using random primers and reverse transcriptase (Promega, Madison, WI, USA) for $45 \mathrm{~min}$ at $42^{\circ} \mathrm{C}$. Subsequently, these solutions were used in a PCR, in which sense oligonucleotide primer for $\mathrm{AT}_{1}$ receptor was from the carboxyl region of the second transmembrane domain (nucleotides 250-270, 5'TGG GCA GTC TAT ACC GCT ATG-3') and the antisense codon was from the sixth transmembrane domain (nucleotides 757-777, 5'-GAA TAT TTG GTG GGG AAC CCA-3') (Ye \& Healy 1992), and for $\mathrm{AT}_{2}$ receptor sense was from the $5^{\prime}$ non-coding region (nucleotides 159-178, 5'-TTG CTG CCA CCA GCA GAA AC-3') and antisense from the $3^{\prime}$ non-coding region (nucleotides 1284-1260, 5'-GTG TGG GCC TCC AAA CCA TTG CTA-3') (Nio et al. 1995). Denaturating, annealing, and extension reactions proceeded 40 times at $94{ }^{\circ} \mathrm{C}$ for $1 \mathrm{~min}, 55^{\circ} \mathrm{C}$ for $2 \mathrm{~min}$ and $72{ }^{\circ} \mathrm{C}$ for $3 \mathrm{~min}$ for $\mathrm{AT}_{1}$, and $94{ }^{\circ} \mathrm{C}$ for $45 \mathrm{~s}, 58^{\circ} \mathrm{C}$ for $45 \mathrm{~s}$ and $72{ }^{\circ} \mathrm{C}$ for $1 \mathrm{~min}$ for $\mathrm{AT}_{2}$. Ten microlitres of the $100 \mu \mathrm{l}$ reaction mixture were then electrophoresed through a $1 \%$ agarose gel and stained with ethidium bromide. Contamination by genomic DNA in sample RNA was excluded by amplifying the sample RNA directly by PCR without reverse transcriptase.

\section{SDS-gel electrophoresis and immunoblotting}

Membrane proteins were combined with an equal volume of $2 \times$ SDS loading dye $(100 \mathrm{mM}$ Tris$\mathrm{HCl}, \mathrm{pH}$ 6.8, $200 \mathrm{mM}$ dithiothreitol, 4\% SDS, $0 \cdot 2 \%$ bromophenol blue, $20 \%$ glycerol and $10 \%$ 
$\beta$-mercaptoethanol), boiled for $3 \mathrm{~min}$ and loaded onto a $10 \%$ SDS-polyacrylamide gel for electrophoresis (Laemmli 1970). After electrophoresis, gels were equilibrated for $15 \mathrm{~min}$ in electroblot buffer $(25 \mathrm{mM}$ Tris- $\mathrm{HCl}, \mathrm{pH} 8 \cdot 3$, containing $150 \mathrm{mM}$ glycine), and the proteins were electrophoretically transferred to poly(vinylidene difluoride) membranes (Immobilon-P membranes, Millipore, Bedford, MA, USA) at $1 \mathrm{~mA} / \mathrm{cm}^{2}$ for $60 \mathrm{~min}$ using a Multiphor II electrophoresis unit (LKB, Bromma, Sweden). After transfer, the membranes were incubated for $1 \mathrm{~h}$ in blocking buffer (PBS containing 5\% BSA). After washing thoroughly with PBS containing $0 \cdot 1 \% \quad(\mathrm{v} / \mathrm{v})$ Tween-20 (PBS+T), membranes were incubated for $1 \mathrm{~h}$ with rabbit anti-Ang II type 1 receptor polyclonal antibody (Biogenesis, Poole, Dorset, UK) or preimmune rabbit serum diluted 1:1000 in $\mathrm{PBS}+\mathrm{T}$, washed with $\mathrm{PBS}+\mathrm{T}$ as before, and then incubated for a further hour with a 1:30 000 dilution of alkaline phosphatase-conjugated goat anti-rabbit IgG (Sigma Chemical Co.). Colour development was carried out in $20 \mathrm{ml} 100 \mathrm{mM}$ Tris- $\mathrm{HCl}$, pH 9.5, containing $100 \mathrm{mM} \mathrm{NaCl}, 5 \mathrm{mM} \mathrm{MgCl}_{2}$ and $132 \mu \mathrm{l} 61 \mathrm{mM}$ nitroblue tetrazolium and $66 \mu \mathrm{l} 173 \mathrm{mM}$ 5-bromo-4-chloro-3-indolyl phosphate (Sigma Chemical Co.). The reaction was stopped with $200 \mu \mathrm{l} 0.5 \mathrm{M}$ EDTA in $50 \mathrm{ml}$ PBS.

\section{Protein determination}

Protein concentrations were determined by the method of Lowry et al. (1951) using BSA as standard.

\section{RESULTS}

To examine the presence and ligand-binding characteristics of the Ang II receptor from thyroid gland, plasma membranes were incubated in the presence of ${ }^{125}$ I-Ang II. As shown in Fig. 1, the Scatchard analysis revealed a single class of binding site with $K_{\mathrm{d}}$ and $\mathrm{B}_{\max }$ values of $3.9 \pm 1.7 \mathrm{nM}$ and $467 \cdot 2 \pm 130 \cdot 0 \mathrm{fmol} / \mathrm{mg}$ protein respectively. A Hill coefficient of $0.98 \pm 0.02(n=3)$ was indicative of a single binding site. Moreover, competition experiments were performed to confirm the pharmacological specificity of ${ }^{125}$ I-Ang II binding in the presence of various concentrations of the specific antagonists Losartan and PD 123319. As shown in the representative experiment of Fig. 2, the $\mathrm{AT}_{1}$ antagonist Losartan was capable of competing for these binding sites $\left(\mathrm{IC}_{50}=1.9 \pm 0.8 \times 10^{-7} \mathrm{M}\right)$, while PD 123319, which is representative of another series of non-peptide Ang II receptor antagonists,

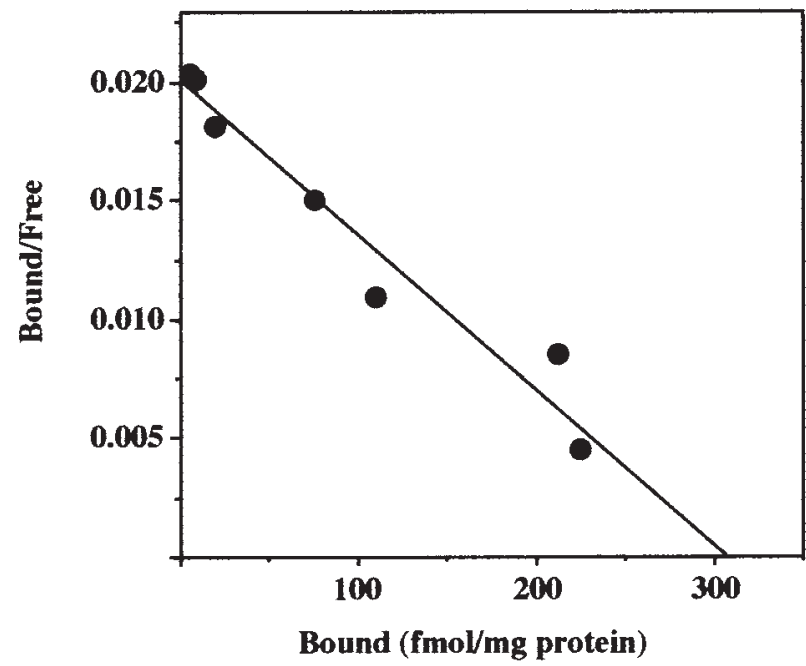

FIGURE 1. Representative Scatchard plot of ${ }^{125}$ I-Ang II binding to plasma membranes from rat thyroid gland.

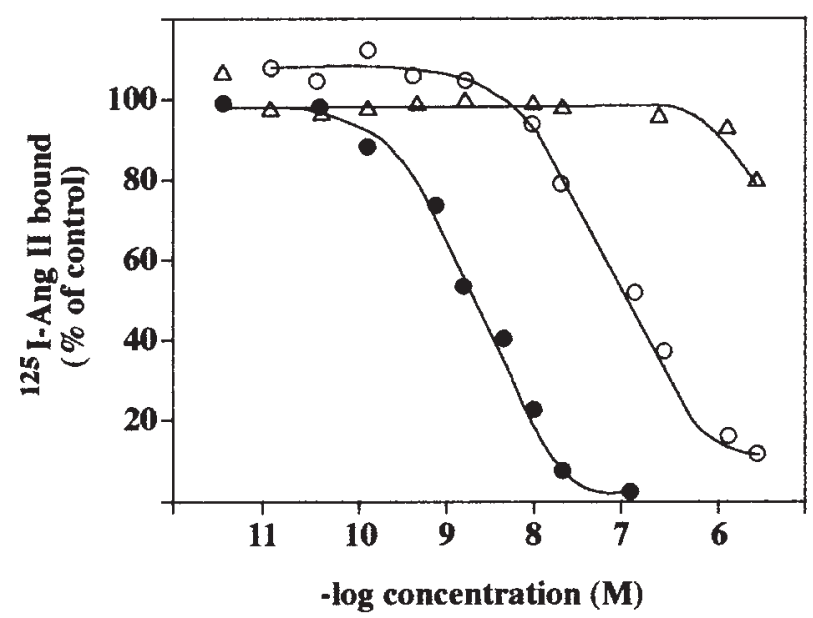

FIGURE 2. Effect of increasing concentration of Ang II (○), Losartan $(\bigcirc)$ and PD $123319(\triangle)$ on specific binding of ${ }^{125} \mathrm{I}$-Ang II to membranes isolated from rat thyroid gland. Each point represents the mean of triplicate determinations.

was basically inactive at concentrations lower than $10^{-6} \mathrm{M}$.

Total RNA was isolated from thyroid gland and analyzed by RT-PCR using primers based on the cloned $\mathrm{AT}_{1}$ and $\mathrm{AT}_{2}$ receptors to assess the presence of the mRNA encoding typical $\mathrm{AT}_{1}$ and $\mathrm{AT}_{2}$ receptors in thyroid gland. As a control, total RNA was isolated from rat adrenal tissue, which contains both $\mathrm{AT}_{1}$ and $\mathrm{AT}_{2}$ receptors. $\mathrm{PCR}$ analysis of isolated DNA using the primers for the $\mathrm{AT}_{1}$ and $\mathrm{AT}_{2}$ receptors yielded products of the expected sizes (data not shown), demonstrating that the 


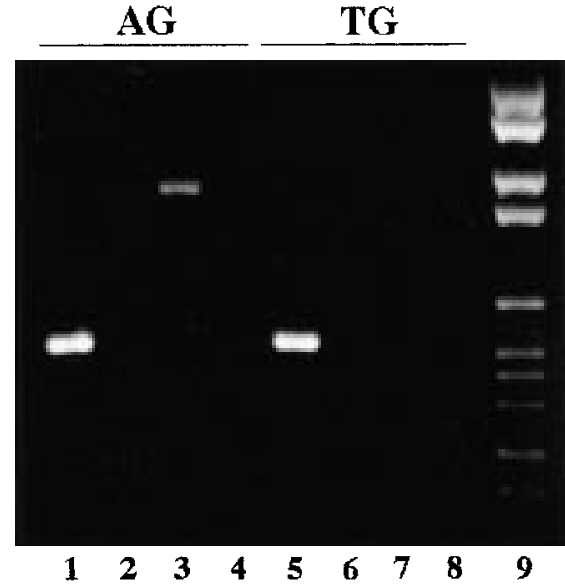

FIGURE 3. Agarose gel electrophoresis of RT-PCR and PCR products of rat adrenal (AG) and thyroid (TG) glands RNA with $\mathrm{AT}_{1}$ and $\mathrm{AT}_{2}$ receptor oligonucleotide primers. Lanes 1 and 5, RT-PCR of $\mathrm{AT}_{1}$; lanes 2 and 6, PCR of $\mathrm{AT}_{1}$; lanes 3 and 7, RT-PCR of $\mathrm{AT}_{2}$; lanes 4 and $8, \mathrm{PCR}$ of $\mathrm{AT}_{2}$; lane 9, DNA markers (pBR328 DNA cleaved with BglI and HinfI).

primers amplified DNA sequences specific for the $\mathrm{AT}_{1}$ or $\mathrm{AT}_{2}$ receptor. As shown in Fig. 3, both $\mathrm{AT}_{1}$ and $\mathrm{AT}_{2}$ mRNA were detected in rat adrenal gland by RT-PCR. However, only $\mathrm{AT}_{1} \mathrm{mRNA}$ was detected in thyroid gland preparations. To rule out contamination of genomic DNA in our RNA preparations, we subjected RNA from tissues used for this study to PCR omitting the reverse transcriptase step; no PCR product was detected on the agarose gel after 40 cycles (Fig. 3).

Our experiments were complemented by immunoblotting analyses to characterize the molecular size of these Ang II binding sites. Three immunoreactive bands with approximate molecular masses of 60,45 and $40 \mathrm{kDa}$ were observed from fresh preparations of rat thyroid gland membranes, while a prominent band at $58 \mathrm{kDa}$ was found in rat adrenal gland samples (Fig. 4).

All results are expressed as means \pm s.D.

\section{DISCUSSION}

The thyroid is an endocrine gland which secretes hormones vital for metabolism and growth. In addition to the well known action of thyroidstimulating hormone in controlling the activity of the thyroid, other humoral agents, such as growth hormone (Grunfeld et al. 1988), insulin and insulin-like growth factor (Santisteban et al. 1987), have been demonstrated to play an important regulatory role in thyroid function.

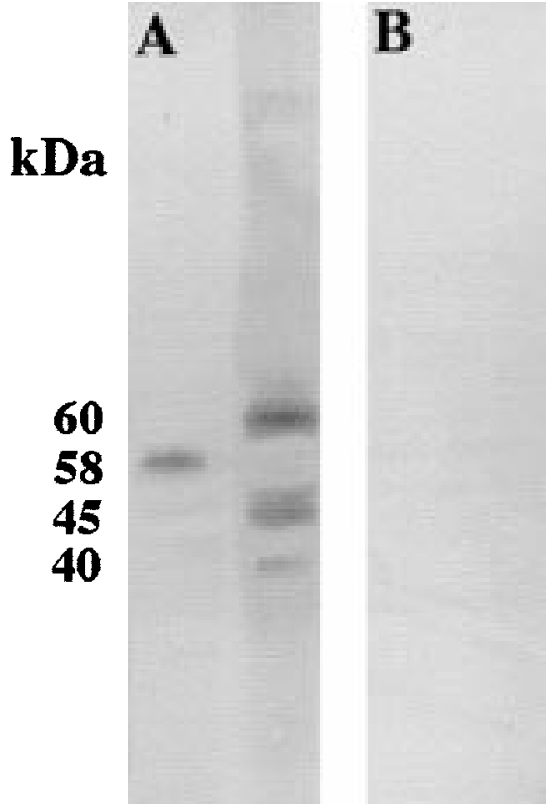

\section{AG TG AG TG}

FIGURE 4. Immunoblotting of SDS gel of solubilized proteins from rat adrenal (AG) and thyroid (TG) glands. Fractionated proteins were transferred onto poly(vinylidene difluoride) membranes and Western blotted with rabbit anti-A $\mathrm{T}_{1}$ receptor polyclonal antibody (A) or preimmune rabbit serum (B).

The results of the present study show, for the first time, the presence of specific receptors for Ang II in the rat thyroid gland, which provides evidence that this gland may also be under the direct control of the RAS.

${ }^{125}$ I-Ang II labels a single population of binding sites in plasma membrane preparations from thyroid gland. The $K_{\mathrm{d}}$ was in good agreement with previously reported data obtained from preparations of several different tissues of the rat (Douglas 1987, Entzeroth \& Hadamovsky 1991). The number of binding sites which can be labelled by the radioligand in our preparations was lower than those reported in rat liver (Booz et al. 1992), but higher than those reported in rat vascular smooth muscle cells (Gunther et al. 1980). This finding indicates that Ang II binding sites in this tissue may not be exclusively located in vascular tissue.

Ang II receptor subtypes may be distinguished by their characteristic affinities for antagonists such as PD 123319 and Losartan (Wong et al. 1992). In competition binding studies of ${ }^{125} \mathrm{I}$-Ang II binding to rat thyroid gland plasma membranes, the non-peptide $\mathrm{AT}_{1}$ receptor antagonist Losartan 
blocked the specific Ang II binding sites, whereas $\mathrm{PD} 121339$, a selective $\mathrm{AT}_{2}$ receptor subtype antagonist, was ineffective at low concentrations. These findings demonstrate that the $\mathrm{AT}_{1}$ receptor subtype is only present in the rat thyroid gland. Definitive evidence for the expression of the $\mathrm{AT}_{1}$ receptor subtype in rat thyroid was obtained by PCR after reverse transcription using primers based on the cloned $\mathrm{AT}_{1}$ and $\mathrm{AT}_{2}$ receptors. Amplification of cDNA for $\mathrm{AT}_{1}$ and $\mathrm{AT}_{2}$ in both rat adrenal and thyroid gland provide good evidence that rat adrenal gland contains $\mathrm{AT}_{1}$ and $\mathrm{AT}_{2}$ receptor subtypes, as has been previously described (Kakar et al. 1992), while the $\mathrm{AT}_{1}$ receptor subtype is only expressed in the thyroid gland.

Variations in carbohydrate content have been demonstrated to contribute to the physical heterogeneity of the Ang II receptor in individual target tissues of a single species and within the same tissue in different species. PAGE studies of solubilized $\mathrm{AT}_{1}$ receptors have revealed bands with molecular masses ranging from 58 to $79 \mathrm{kDa}$ (Catt et al. 1987). In order to obtain more information on the molecular structure of the Ang II receptor from thyroid gland, our study was complemented by immunoblotting analyses. Western blot assays identified three prominent bands of approximately 60,45 and $40 \mathrm{kDa}$ in fresh plasma membrane preparations from thyroid tissue, which appeared to be related to different degrees of glycosylation of the receptor molecule. Similar experiments, using plasma membranes prepared from COS-7 cells expressing the $\mathrm{AT}_{1}$ receptor subtype, identified a $40 \mathrm{kDa}$ immunoreactive protein (Barker et al. 1993), corresponding to the predicted value for unmodified $\mathrm{AT}_{1}$ receptor (Sandberg et al. 1992). Moreover, a $60 \mathrm{kDa}$ immunoreactive band has been detected in plasma membrane preparations from glomerulosa cells (Vinson et al. 1994), which represent the mature glycosylated $\mathrm{AT}_{1}$ receptor subtype (Desarnaud et al. 1993).

In summary, the present study demonstrates the presence of type $\mathrm{AT}_{1}$ Ang II binding sites in the rat thyroid gland.

\section{ACKNOWLEDGEMENTS}

We would like to thank Dr Marc de Gasparo (Ciba-Geigy Ltd, Basel, Switzerland) and Parke Davis (Ann Arbor, MI, USA) for providing Losartan and PD 123319 respectively.

This work was supported by a grant PB94-1476 from the Dirección General de Investigación Científica y Técnica, Madrid, Spain.

\section{REFERENCES}

Barker S, Marchant W, Ho MM, Puddefoot JR, Hinson JP, Clark AJL \& Vinson GP 1993 A monoclonal antibody to a conserved sequences in the extracellular domain recognizes the angiotensin II $\mathrm{AT}_{1}$ receptor in mammalian target tissues. Fournal of Molecular Endocrinology 11 241-245.

Booz GW, Conrad KM, Hess AL, Singer HA \& Baker KM 1992 Angiotensin II binding sites on hepatocyte nuclei. Endocrinology 130 3641-3649.

Breault L, Lehoux JG \& Gallo-Payet N 1996 Angiotensin II receptors in the human adrenal gland. Endocrine Research 22 $355-361$.

Catanzaro DF 1995 The molecular biology of renin gene expression. In Hypertension: Pathophysiology, Diagnosis and Management, pp 1589-1605. Eds JH Laragh \& BM Brenner. New York: Raven.

Catt KJ, Carson MC, Hausdorff WP, Leach-Harper CM, Baukal AJ, Guillemette G, Balla T \& Aguilera G 1987 Angiotensin II receptors and mechanisms of action in adrenal glomerulosa cells. Fournal of Steroid Biochemistry 27 915-927.

Chomczynki P \& Sacchi N 1987 Single-step method of RNA isolation by acid guanidinium thiocyanate-phenol-chloroform extraction. Analytical Biochemistry 162 156-159.

De Gasparo M, Bottari S \& Levens NR 1995 Characteristics of angiotensin II receptors and their role in cell and organ physiology. In Hypertension: Pathophysiology, Diagnosis and Management, pp 1695-1720. Eds JH Laragh \& BM Brenner. New York: Raven.

Desarnaud F, Marie J, Lombard C, Larguier R, Seyer R, Lorca T, Jard S \& Bonnafous J-C 1993 Deglycosylation and fragmentation of purified rat liver angiotensin II receptor: application to the mapping of hormone-binding domains. Biochemical Fournal 289 289-297.

Douglas JG 1987 Angiotensin II receptor subtypes of the kidney cortex. American fournal of Physiology 253 F1-F7.

Entzeroth M \& Hadamovsky S 1991 Angiotensin II receptors in the rat lung are of the AII-1 subtype. European Fournal of Pharmacology 206 237-241.

Glossmann H, Baukal A \& Catt KJ 1974 Properties of the angiotensin II receptors in the bovine and rat adrenal cortex. Fournal of Biological Chemistry 249 644-666.

Grunfeld C, Sherman BM \& Cavalieri RR 1988 The acute effects of human growth hormone administration on thyroid function in normal men. Fournal of Clinical Endocrinology and Metabolism 67 1111-1114.

Gunther S, Gimbrone MA \& Alexander RW 1980 Identification and characterization of the high affinity vascular angiotensin II receptor in rat mesenteric artery. Circulation Research 47 278-286.

Harris RC \& Inagami T 1995 Molecular biology and pharmacology of angiotensin receptor subtypes. In Hypertension: Pathophysiology, Diagnosis and Management, pp 1721-1738. Eds JH Laragh \& BM Brenner. New York: Raven.

Hermann JG, Simon M \& Fuchs E 1991 Autoradiographic characterization of angiotensin receptor subtype in fetal and adult human kidney. American Fournal of Physiology 262 F326-F331.

Janiak P, Pillon A, Prost JF \& Vilaine JP 1992 Role of angiotensin subtype 2 receptor neointima formation after vascular injury. Hypertension 20 737-745.

Jiménez E, Montiel M, Narváez JA \& Morell M 1984 Renin-angiotensin system in hypothyroid rats: effects of potassium iodide and triiodo-L-thyronine. Acta Endocrinologica 105 505-510. 
Kakar SS, Sellers JC, Devor DC, Musgrove LC \& Neill JD 1992 Angiotensin II type-1 receptor subtype cDNAs: differential tissue expression and hormonal regulation. Biochemical and Biophysical Research Communications 183 1090-1096.

Kambayashi Y, Bardhan S, Takahashi K, Tsuzuki S, Inui H, Hamakubo T \& Inagami T 1993 Molecular cloning of a novel angiotensin II receptor isoform involved in phosphotyrosine phosphate inhibition. The Fournal of Biological Chemistry 268 24543-24546.

Laemmli UK 1970 Cleavage of structural proteins during the assembly of the head of bacteriophage T4. Nature 227 680-685.

Lowry OH, Rosebrough NJ, Farr AL \& Randall RJ 1951 Protein measurement with the Folin phenol reagent. Fournal of Biological Chemistry 139 265-275.

Marchant C, Brown L \& Sernia C 1993 Renin-angiotensin system in thyroid dysfunction in rats. Fournal of Cardiovascular Pharmacology 22 449-455.

Matillas MJ, Montiel M \& Jiménez E 1993 Angiotensin II (AII) and adrenal gland AII receptors in rats with congenital hypothyroidism. Fournal of Endocrinology 137 231-238.

Montiel M, Jiménez E, Narváez JA \& Morell M 1984 Aldosterone and plasma renin activity in hyperthyroid rats: effects of propranolol and propylthiouracil. Fournal of Endocrinological Investigation 7 559-562.

Munson PJ \& Rodbard D 1980 Ligand: a versatile computerized approach for characterization of ligand-binding system. Analytical Biochemistry 107 220-239.

Naftilan AJ, Pratt RE \& Dzau VJ 1989 Induction of plateletderived growth factor A-chain and c-myc gene expressions by angiotensin II in cultured rat vascular smooth muscle cells. Fournal of Clinical Investigation 83 1419-1424.

Nio Y, Matsubara H, Murasawa S, Kanasaki M \& Inada M 1995 Regulation of gene transcription of angiotensin II receptor subtypes in myocardial infarction. Fournal of Clinical Investigation 95 46-54.

Ruiz M, Montiel M, Jiménez E \& Morell M 1987 Effect of thyroid hormones on angiotensinogen production in the rat in vivo and in vitro. Fournal of Endocrinology 115 311-315.

Sandberg K, Ji H, Clark AJL, Shapira H \& Catt KJ 1992 Cloning and expression of a novel angiotensin II receptor subtype. Fournal of Biological Chemistry 267 9455-9458.

Santisteban P, Kohn LD \& Di Lauro R 1987 Thyroglobulin gene expression is regulated by insulin and insulin-like growth factor Y, as well as thyrotropin, in FRTL-5 thyroid cells. Fournal of Biological Chemistry 262 4048-4052.

Sasaki K, Yamano Y, Bardhan S, Iwai N, Murray JJ, Hasegawa M, Matsuda Y \& Inagami T 1991 Cloning and expression of a complementary DNA encoding a bovine adrenal angiotensin II type-1 receptor. Nature $\mathbf{3 5 1}$ 230-233.

Schelling P, Fischer H \& Ganten D 1991 Angiotensin and cell growth: a link to cardiovascular hypertrophy? Fournal of Hypertension 9 3-15.

Steckelings UM, Artuc M, Paul M, Stoll M \& Henz BM 1996 Angiotensin II stimulates proliferation of primary human keratinocytes via a non- $\mathrm{AT}_{1}$, non- $\mathrm{AT}_{2}$ angiotensin receptor. Biochemical and Biophysical Research Communications 229 329-333.

Vinson GP, Ho MM, Puddefoot JR, Teja R \& Barker S 1994 Internalisation of the type 1 angiotensin II $\left(\mathrm{AT}_{1}\right)$ and angiotensin II function in the adrenal zona glomerulosa cell. Fournal of Endocrinology 141 R5-R9.

Viswanathan M \& Saavedra JM 1992 Expression of angiotensin II $\mathrm{AT}_{2}$ receptors in the rat skin during experimental wound healing. Peptides 13 783-786.

Viswanathan M \& Saavedra JM 1994 Angiotensin II receptor subtypes and growth. In Angiotensin Receptors, pp 205-219. Eds JM Saavedra \& BMWM Timmermans. New York: Plenum.

Whitebread S, Mele M, Kamber B \& De Gasparo 1989 Preliminary biochemical characterization of two angiotensin II receptor subtypes. Biochemical and Biophysical Research Communications 163 284-291.

Wong PC, Chiu AT, Duncia JV, Herblin WF, Smith RD \& Timmermans BMWM 1992 Angiotensin II receptor antagonists and receptor subtypes. Trends in Endocrinology and Metabolism 3 211-217.

Ye MQ \& Healy DP 1992 Characterization of an angiotensin type-1 receptor partial cDNA from rat kidney: evidence for a novel $\mathrm{AT}_{1 \mathrm{~B}}$ receptor subtype. Biochemical and Biophysical Research Communications 185 204-210.

Zemel S, Millan MA, Feuillan P \& Aguilera G 1990 Characterization and distribution of angiotensin-II receptors in the primate fetus. Fournal of Clinical Endocrinology and Metabolism 71 1003-1007.

REVISED MANUSCRIPT RECEIVED 3 November 1997 